\title{
NARASI KEKERASAN SEKSUAL PADA GAY ANAK: NEGARA ABSEN DALAM PERLINDUNGAN?
}

\author{
NIKODIMUS NIKO \\ Program Studi Sosiologi, Pascasarjana FISIP, \\ Universitas Padjadjaran Bandung \\ nicoeman7@gmail.com
}

\begin{abstract}
Gay were victims of sexual abuse who tends to blame and thought to be the cause of sexual violence. Sexual orientation tend to be justification the cause of action of sexual abuse. This paper describes expleration paradox of sexual violence on gay children, and act done by state in effort to protection the victims. The reseacrh method used was descriptive analysis approach. Data collection used was secondary data from literature and scientific journals. On gay children as the victim justifiying as a criminal of sexual violence because his sexual orientation.
\end{abstract}

\section{PENDAHULUAN}

Kekerasan seksual pada gay di Indonesia tidak dapat menutup mata untuk bersuara. Aksi dan kampanye untuk menyatakan "Indonesia Darurat Kekerasan Seksual", namun sayang kekerasan seksual terhadap gay seringkali diabaikan. Situasi darurat merefleksikan bahwa semua gender berpotensi mengalami kekerasan seksual, tidak terkecuali gay; yang merupakan salah satu bentuk keragaman gender.

Kekerasan seksual pada anak paling marak terjadi, bahkan dalam pemberitaan media massa korban hingga meninggal dunia. Tidak ada pengecualian gender korban, termasuk gay anak berpotensi besar mendapatkan kekerasan seksual. Saya pernah bertanya pada seorang gay yang masih berumur 16 tahun, ia rela menjadi objek pelecehan untuk mendapatkan uang, karena berasal dari keluarga miskin Pelaku tindak kekerasan pada gay anak ini merupakan kalangan pedofilia.

Pedofilia menurut Yuwono (2015) adalah ketertarikan seksual orang dewasa terhadap anakanak pra-pubertas (belum mengalami menstruasi dan belum dapat dibuahi bagi anak perempuan dan belum dapat menghasilkan sperma bagi anak laki-laki). Pedofilia ini terbagi menjadi dua, yaitu Pedofilia Heteroseksual dan Pedofilia Homoseksual (Khaidir, 2007). Menurut Erich Fromm (dalan Yuwono, 2015) mengidentifikasikan pedofilia adalah penyakit penyimpangan seksual yang masuk dalam kategori sadisme, bentuknya berkisar dari keinginan menyakiti korban, melecehkannya, membelenggunya, sampai dengan memaksa korban sepenuhnya tunduk kepadanya.

Kekhawatiran kita bersama adalah agar hal berulang tidak terjadi kembali kepada anak-anak kita, baik dari kalangan kelas atas, kelas menengah maupun kelas bawah. Karena anak yang rentan mengalami pelecehan dan kekerasan seksual adalah anak yang berasal dari keluarga kelas bawah (miskin). Niko (2016) dalam studinya mengungkapkan bahwa anak-anak laki-laki (gay anak) yang miskin menjadi prostitute (pelacur) untuk mendapatkan uang dan makan. Hal ini juga diungkapkan Person (2015) bahwasannya anak-anak sangat rentan masuk dalam dunia pelacuran.

Narasi kekerasan seksual pada anak, tersudutkan karena orientasi seksual gay. Menurut Siti Musdah Mulia (2010, dalam Sa'dan, 2015) orientasi seksual merupakan kodrat, ia adalah pemberian Tuhan, tidak dapat diubah, setiap manusia tak memiliki hak untuk memilih dilahirkan dengan orientasi seksual tertentu. Namun, mereka selalu dianggap pelaku dan bukan korban, karena gay dianggap sebagai penyimpangan bukan orientasi seksual. Oleh karena itugay selalu dianggap berperan 
sebagai pelaku. Secara umum, anak-anak yang menjadi korban dari tindak kekerasan sebenarnya tidak dibatasi oleh perbedaan jenis kelamin. Dalam arti bahwa baik anak lakilaki maupun anak perempuan keduanya potensial dan merupakan sasaran empuk dari perlakuan semena-mena yang berkembang di masyarakat (Suyanto, 2013).

Kekerasan seksual adalah sebuah kejahatan yang berdampak sangat besar pada korbankorbannya, tidak hanya fisik, tetapi juga psikologis (Yolandasari, 2015). Dampak yang dirasakan bahkan hingga seumur hidup oleh korban. Akibat pelecehan seksual yang terjadi pada anak memang akan berdampak lebih panjang terhadap psikologisnya. Anak akan diliputi perasaan takut, malu, dendam, marah, penuh kebencian yang tadinya ditujukan kepada orang yang telah melecehkannya, kemudian menyebar kepada obyek atau orang lain.

Penderitaan macam apakah yang dialami anak korban tindak kekerasan? Secara teoritis, anak yang menjadi korban tindak kekerasan bisa saja mengalami luka fisik yang ringan sampai yang serius, tetapi tak jarang terjadi penderitaan itu melukai ruang psikologis anak dan menimbulkan rasa traumatis yang mendalam akibat ulah orang dewasa yang sebelumnya sama sekali tidak pernah mereka bayangkan (Suyanto, 2013).Dampak-dampak yang dimaksud juga dapat terjadi terhadap korban kekerasan seksual pada gay anak. Traumatik masa lalu ini juga dialami oleh korban kekerasan seksual pada gay anak, mereka cenderung menutup diri dari lingkungan sosialnya.

Gay anak adalah anak-anak yang memiliki orientasi seksual homoseksual (laki-laki menyukai laki-laki). Mereka ini merupakan usia yang sangat rentan mendapatkan pelecehan, diskriminasi bahkan penolakan dari masyarakat dan keluarga. Usia mereka yang masih belum dewasa menjadi salah satu alasan bahwa keluarga adalah tempat bagi mereka berlindung. Namun kenyataannya, justru keluarga adalah tempat pelecehan dan kekerasan itu bermula.

Pada studi yang dilakukan Suyanto (2013) menyebutkan bahwa bahaya yang mengancam anakanak ternyata bukan dari orang lain atau para penjahat profesional yang tidak dikenal korban, tetapi justru ancaman itu kerap kali muncul dari orang-orang yang dekat dengan korban, atau bahkan orangorang yang semula diharapkan dapat menjaga tempat berlindung. Dalam hal ini negara mengabaikan perlindungan terhadap anak-anak korban kekerasan seksual pada gay anak di Indonesia.

\section{METODOLOGI}

Tulisan ini menggunakan metode penulisan deskriptif analitis. Data yang digunakan adalah data sekunder yang bersumber dari buku, jurnal ilmiah, dan media online. Adapun yang menjadi objek dalam tulisan ini adalah eksplorasi paradoksal kekerasan seksual pada gay anak. Analisis konseptual yang ingin dicapai yaitu ingin mencari hubungan sebab-akibat terjadinya kekerasan seksual pada gay anak.

\section{KEKERASAN SEKSUAL PADA GAY ANAK}

Kekerasan seksual adalah semua bentuk pemaksaan dan ancaman yang menyerang korban secara seksual. Dalam pasal 289 KUHP disebutkan barang siapa dengan kekerasan atau ancaman kekerasan memaksa seseorang melakukan atau membiarkan melakukan pada dirinya perbuatan cabul, dihukum karena merusakkan kesopanan dengan hukuman penjara selama-lamanya sembilan tahun (Yuwono, 2015). Pasal ini berlaku untuk semua kalangan, dan semua gender, jadi tidak ada pengecualian. Anak laki-laki dan anak perempuan memiliki kerentanan yang sama mendapatkan kekerasan seksual dari orang-orang dewasa. 
Penting kiranya untuk mengetahui bentuk-bentuk kekerasan seksual yang kerapkali terjadi pada anak-anak. Menurut Thamrin dan Farid (dalam Yuwono, 2015) bentuk-bentuk kekerasan seksual terhadap anak memiliki cakupan yang sangat luas, antara lain, perkosaan, sodomi, seks oral, sexual gesture (serangan seksual secara visual termasuk eksibisionisme), sexual remark (serangan seksual secara verbal), pelecehan seksual, pelacuran anak, dan sunat klentit pada anak perempuan.

Kekerasan seksual yang terjadi pada gay anak dapat meliputi; sodomi (secara paksa), sexual gesture, sexual remark, pelecehan seksual dan pelacuran anak. Berdasarkan kajian yang dilakukan oleh ILO (International Labour Organization) tahun 2004 menunjukkan bahwa selain masalah ekonomi dan sosial, faktor yang menyebabkan anak-anak rentan dilacurkan, khususnya untuk anak laki-laki, adalah keinginan untuk mempunyai gaya hidup yang materialistis dan lingkungan yang tidak menyenangkan. Menurut Niko (2016) kegiatan prostitusi laki-laki yang masih anak-anak di Indonesia bersifat terselubung, berbeda dengan prostitusi anak laki-laki di Thailand yang bersifat terbuka.

Prostitusi anak sangat rentan menjadi korban kekerasan seksual dari client atau pengguna jasa mereka, yang adalah orang-orang dewasa. Kekerasan seksual pada anak laki-laki melalui anal seks, tentu akan mengalami sakit pada bagian anus, dan harus mendapatkan penyembuhan fisik secara medis. Selain itu, kekerasan seksual terhadap anak ini memiliki daya rusak psikologis; anak akan mengalami trauma psikis saat dan setelah mengalami kekerasan seksual.

Kekerasan seksual pada gay anak terjadi karena; pertama, situasi ekonomi atau kemiskinan. Anak laki-laki metan masuk dana dunia pelacuran karena keluarga mereka tidak memiliki akses ekonomi yang memadai. Anak laki-laki yang menjadi pelacurrentan mendapatkan pelecehan dan kekerasan seksual. Kedua, lemahnya perlindungan hukum (negara). Pada materi pasal 293 ayat (1) disebutkan bahwa barang siapa dengan mempergunakan hadian atau perjanjian akan memberi uang atau barang, dengan salah mempergunakan pengaruh yang berlebih-lebihan yang ada disebabkan oleh perhubungan yang sesungguhnya ada atau dengan tipu, sengaja membujuk orang yang belum dewasa yang tidak bercacat kelakuannya, yang diketahuinya atau patut harus disangkanya belum dewasa, akan melakukan perbuatan cabul dengan dia atau membiarkan dilakukan perbuatan yang demikian pada dirinya, dihukum penjara selama-lamanya lima tahun (Yuwono, 2015).

Pada pasal 293 ayat (1) menyebutkan bahwa anak-anak yang tidak bermoral adalah bukan korban. Menurut Soesilo (dalam Yuwono, 2015) kata "cacat" dalam pasal tersebut adalah pelacur; "Tidak bercacat kelakuannya: hanya mengenai kelakuan dalam hal seksual. membujuk seorang pelacur, meskipun belum dewasa, tidak masuk disini, karena pelacur sudah bercacat kelakuannya dalam lapangan seksual". Menurut penulis pasal ini sangat menciderai keadilan bagi gay anak (dalam prostitusi) sebagai korban kekerasan seksual. Anak-anak gay yang terjun dalam dunia prostitusi tidak mendapatkan perlindungan hukum, karena KUHP (Kitab Undang-Undang Hukum Pidana) memposisikan mereka sebagai penggoda, bukan sebagai korban yang seharusnya mendapatkan perlindungan. ILO (2004) dalam studinya menyatakan bahwa anak-anak yang terlibat dalam pelacuran tetap saja dilihat sebagai pelaku kejahatan dan bukan sebagai korban di mata penegak hukum.

Masih tergolong sedikit organisasi yang menyuarakan penghapusan tindak kejahatan seksual terhadap anak di Indonesia. Namun, aksi penghapusan sulit untuk terealisasi. Bagaimana menghapus tindak kejahatan seksual pada anak-anak gay, jika orientasi seksual gay sendiri masih menjadi kontroversi panjang dan mengalami diskriminasi. ILO (2004) menyebutkan "sayangnya, mereka yang melakukan kegiatan untuk menghapuskan kerentanan anak untuk diperdagangkan dan dieksploitasi secara seksual masih sedikit jumlahnya dan kegiatan biasanya tidak berkelanjutan mengingat umumnya hanya sebatas proyek. 
Di Indonesia sendiri homoseksualitas tidak ilegal, pada november 2006 komisi Ahli hak asasi manusia (HAM) dari 25 negara, menyepakati Yogyakarta Principles on the Application of International Human Rights Law in Relation to Sexual Orientation and Gender Identity, yang menetapkan prinsip-prinsip HAM guna mengatasi pelecehan hak asasi manusia yang dialami oleh kelompok Lesbian, Gay, Biseksual, Transgender (LGBT) dan transeksual (Andajani, Lubis \& Graham-Davis). Ini menunjukkan bahwa negara Indonesia menghormati hak-hak LGBT, tetapi pada implementasinya, negara sendiri yang menciderai.

\section{KRIMINALISASI GAY ANAK DAN PERLINDUNGAN NEGARA?}

Diskriminasi dan kriminalisasi terhadap kelompok minoritas gay merupakan bentuk kekerasan yang berkepanjangan. Indonesia adalah negara pengadopsi heteronormatif paling ekstrem dimana konsep normalitas seksual dilihat berdasarkan pada perkawinan laki-laki dan perempuan (heteroseksual). KUHP secara tegas melarang praktik homoseksualitas terhadap anak-anak di bawah umur (gay anak), namun tidak menawarkan solusi lain; selain penghukuman penjara dan denda.

Pada Undang-Undang Nomor 35 Tahun 2014 yang merupakan Perubahan Atas UndangUndang Nomor 23 Tahun 2002 Tentang Perlindungan Anak, pasal 21 huruf (1) menyatakan bahwa; "negara, pemerintah, dan pemerintah daerah berkewajiban dan bertanggung jawab menghormati pemenuhan Hak Anak tanpa membedakan suku, agama, ras, golongan, jenis kelamin, etnik, budaya dan bahasa, status hukum, urutan kelahiran, dan kondisi fisik dan/atau mental." Pada pasal ini jelas, bahwa negara seharusnya memberikan perlindungan bagi setiap anak, tidak ada pengecualian terhadap anak-anak yang memiliki orientasi seksual gay. Tetapi kerapkali dijumpai bahwasannya masih terdapat diskriminasi hukum dalam melindungi korban kekerasan seksual anak.

Ketika saya bertanya kepada seorang gay yang masih berusia remaja di Kota Pontianak, "mengapa kamu mau menjadi gay??" jawaban anak itu "aku juga tidak tabu, aku tidak, pernah meminta menjadi gay". Anak-anak tidak dapat memilih orientasi seksual, jika mereka dipaksa "harus" heteroseksual, itu merupakan bentuk penyiksaan kepada anak. Konsep heteronormatif hanya akan menjadi mimpi buruk yang menyeramkan bagi anak-anak yang sudah mengetahui orientasi seksualnya sebagai gay.Anak-anak dikekang, dan tidak diberikan kebebasan untuk memilih orientasi seksual apa yang mereka inginkan. Sebagai akibatnya, terdapat banyak anak-anak yang kemudian mencoba berontak dan terjun menjadi prostitusi, kemudian mengalami kekerasan seksual.

Pada dasarnya perkawinan homoseksual tidak diakui oleh negara. Hal ini tertuang dalam Undang-Undang Perkawinan Nomor 1 Tahun 1974, yang mengatur tentang perkawinan antara lakilaki dan perempuan, tidak mengatur tentang perkawinan laki-laki dan laki-laki atau perempuan dan perempuan. Kerangka politik dan konteks sosial yang heteronormatif ini membuat mereka yang memiliki gender dan orientasi seksualitas yang berbeda, menjadi outsider, kelompok yang terpinggirkan bahkan tak jarang mereka dikejar-kejar dan dihukum oleh aparat penegak hukum (Andajani, Lubis \& Graham-Davies, 2015).

Perjuangan kelompok homoseksual di negeri ini boleh dibilang turut menyumbang perkembangan studi seksualitas dalam konteks ilmu sosial (Wijaya, 2015). Sebenarnya di kalangan akademisi ilmu sosial sendiri, masih banyak yang beranggapan bahwa tabu dan vulgar jika membicarakan seksualitas dalam lingkungan akademik (sekolah dan kampus). Bahkan keluarga di Indonesia belum terbiasa berdialog tentang seks (Jurnal Perempuan, 2005). 


\section{PENUTUP}

Indonesia mengakui dan menghormati hak-hak seksual bagi kelompok-kelompok tertentu, namun hukum nasional dan internasional hanya sebatas formalitas. Realitanya, kelompok gay secara khusus dipandang rendah oleh kelompok-kelompok tertentu, terlebih kelompok yang bersarung keagamaan; negara diam atas hal ini. Dalam interaksi sehari-hari pun kelompok gay rentan terhadap diskriminasi, marginalisasi, dan stereotipe. Hal ini akan berimbas kepada korban kekerasan seksual yang dialami oleh kelompok gay yang masih anak-anak. Tidak mengalami kekerasan seksual saja, mereka sudah mengalami kekerasan psikologis dalam lingkungan pergaulan mereka.Kekerasan seksual yang rentan terhadap gay anak ini merupakan jalan bagi kelompok-kelompok tertentu untuk mengkriminalkan kelompok gay secara keseluruhan. Belum ada hukum tertulis secara khusus untuk melindungi hak-hak kelompok minoritas gay di Indonesia, oleh karena itu korban kekerasan seksual pada gay anak rentan dihadapkan dengan ketidakadilan di mata hukum.

\section{REFRENSI}

Andajani, S., Lubis, D., \& Graham-Davies, S. 2015. Raz̧ia Terbadap LGBT Sebagai Agenda Moralitas Palsu: Kajian Pemberitaan Media di Indonesia. Jurnal Perempuan. Vol. 20 (4), Hal. 97-107.

Khaidir, M. 2007. Penyimpangan Seks (Pedofilia).Jurnal Kesehatan Masyarakat. Vol. 2 (2), Hal. 83-89.

Niko, N. 2016. Boy Prostitute: Kemiskinan dan Life Style. Yogyakarta: Deepublish.

Person, K. 2015. Sexual Violence during the Holocaust: The Case of Forced Prostitution in the Warsan Ghetto. Shofar: An Interdisiplinary Journal of Jewish Studies. Vol. 33 (2), P. 103-121.

Sa'dan, M. 2015. LGBT, Agama dan HAM: Kajian Pemikiran Khaled M. Abou ElFadl. Jurnal Perempuan. Vol. 20 (4), Hal. 176-194.

. 2005. Pendidikan Seks, Salah Satu cara Menyelamatkan Seksualitas Perempuan. Jurnal Perempuan. Vol. 41 (1), Hal. 106-107.

Suyanto, B. 2013. Masalah Sosial Anak. Jakarta: KENCANA.

Undang-Undang Nomor 35 Tahun 2014 Perubahan Atas Undang-Undang Nomor 23 Tahun 2002 Tentang Perlindungan Anak.

Wijaya, H. Y. 2015. Memetakan Tubuh, Gender, dan Seksualitas dalam Kajian Queer. Jurnal Perempuan. Vol. 20 (4), Hal. 122-141.

2004. Perdagangan Anak Untuk Tujuan Pelacuran di Jakarta dan Jawa Barat. International Labour Organization.

Yolandasari, A. R. 2015. Penyebab atau Penyembub? Kekerasan Seksual terbadap Lesbian, Biseksual, dan Transgender Female-to-Male di Indonesia. Jurnal Perempuan. Vol. 20 (4), Hal. 86-96.Yuwono, I. D. 2015. Penerapan Hukum Dalam Kasus Kekerasan Seksual Terhadap Anak. Yogyakarta: Pustaka Yustisia. 


\section{RAHEEMA: \\ Jurnal Studi Gender dan Anak}

Raheema adalah jurnal berkala ilmiah yang mempublikasikan hasil-hasil kajian studi gender dan anak. Raheema juga memuat tinjauan buku ilmiah (book review) dalam bidang kajian studi gender dan anak yang dilakukan oleh para akademisi dan praktisi sesuai dengan keahlian masing-masing. Raheema terbit dua kali setahun pada Pusat Studi Gender dan Anak LP2M IAIN Pontianak.

Tema:

Perlindungan Hak-hak Perempuan dan Anak: Perspektif Islam

Sub Tema:

1. Konsep keadilan perempuan dalam Islam.

2. Studi kritis gerakan feminism di dunia Islam.

3. Kekerasan dalam rumah tangga: Tinjauan Islam dan Hak Asasi Manusia.

4. Aborsi dalam Tinjauan Islam dan Hak Asasi Manusia.

5. Membangun Karakter Mulia pada Anak

6. Kesetaraan Gender dalam Berbagai Perspetif

7. Implementasi pengarusutamaan gender dalam pendidikan Islam.

Persyaratan Artikel:

1. Naskah harus bersumber dari hasil penelitian dan merupakan karya sendiri yang belum pernah dipublikasikan atau tidak sedang dalam proses pengajuan untuk publikasi ke media lain.

2. Artikel dapat ditulis dalam Bahasa Indonesia dan Bahasa Inggris.

3. Panjang tulisan antara tidak boleh kurang dari 4.000 kata, dan tidak boleh lebih dari 6000 kata, sudah termasuk gambar, ilustrasi dan daftar pustaka.

4. Artikel harus didahulului oleh halaman judul yang berisikan judul artikel, nama penulis, a liasi, nomor telefon dan fax serta e-mail.

5. Tulisan juga harus disertai dengan abstrak dan tidak lebih dari 200 kata, sertakan juga 3 - 5 kata kunci (keyword).

6. Artikel di tulis dengan font Book Antiqua 12 dan spasi berjarak 1,5.

7. Teknik pengutipan dan rujukan menggunakan body note, dengan menyebutkan nama pengarang, tahun dan halaman jika perlu)

8. Penulisan referensi menggunakan format Harvard (the Harvard Referencing System).

- Buku:

McLennan, Gregor., 2006. Sociologial Cultural Studies: Re exivity and positivity in the human sciences. London: Palgrave Macmillan.

- Buku (editor)

Davidson, Jamie. S dan David Henley (Editor)., 2007. The Revival of Tradition in Indonesian Politics: The development of adat from colonialism to indigenism. London: Routledge. 
- Bab dalam Buku:

Stuers, Cora Vreede-de., 1987. The Life of Rangkayo Rahmah El Yunusiah: The facts and the image. Dalam: Locher-Scholten, Elsbeth dan Anke Niehof., 1987. Indonesian Women in Focus: Past and present notions. Dordrect-Holland: Foris Publication, Hal. $52-57$.

- Artikel Jurnal:

Benda-Beckmann, Keebet von dan Franz von Benda-Beckmann., 1978. Residence in Minangkabau Nagari. Indonesia and the Malay world, 6 (15). Hal. 6 - 17.

- Tesis dan Disertasi:

Hadler, Jeffrey., 2000. Place Like Home: Islam, matriliny adn the history of family in minangkabau. Disertasi doktor. Itacha: Cornell University.

- Makalah dalam Seminar/Konferensi:

Navis, A.A., 1985. Perempuan Dalam Masyarakat Matrilini Minangkabau. Dalam: Seminar Kebudayaan Minangkabau. Bukittinggi 19 dan 20 Agustus 1985.

- Website:

Indonesia: Program for Community Empowerment. In Rural Areas. 2011. [Diakses 2 Maret 2011\}. http://www.worldbank.org/in/country/indonesia/overview.

9. Artikel yang memenuhi syarat akan direview oleh seorang blind reader, dan hasil review akan dikembalikan kepada penulis untuk diperbaiki sebelum diterbitkan.

10. Hak cipta (copyright) atas artikel yang dipublikasikan melalui Raheema sepenuhnya menjadi hak milik Redaksi.

11. Artikel dikirimkan ke alamat berikut:

Redaksi Raheema

Pusat Studi Gender dan Anak

LP2M Institut Agama Islam Negeri (IAIN) Pontianak

Jalan Suprapto No. 19 Pontianak, KalBar. 78121.

Telpon/Fax: 0561-570421,

e-mail:syamsul_kurniawan@yahoo.com 